\title{
Fiona Price
}

\section{A FIRMER AND MORE FERTILE YOUTH}

IN THE YEAR of her forty-sixth birthday, Mrs Dawkins found herself troubled by lustful thoughts. The thoughts in themselves were not a problem. Truth be told, Mrs Dawkins felt proud of her reawakened libido, viewing it as a kind of medal that connected her, however tenuously, to a firmer and more fertile youth. The problem was that none of her lustful thoughts involved Mr Dawkins.

Naturally, this had not always been the case. When the Dawkins' had married, Mr Dawkins had inspired considerable lust in his bride. At twentyeight, he had a thicket of dark curls and shoulders as broad and bulky as the leather armchair his parents bought them as a wedding present. At forty-eight, however, with the last of his curls smeared across his scalp, he looked more like the matching leather beanbag, especially when kneeling in the garden with his bottom thrust into the air.

Mrs Dawkins averted her gaze from her weeding, wobbly husband with a sigh. Even if the target of her desires had been Mr Dawkins, she doubted whether he would have satisfied it. In the last few years he'd been more interested in slug pellets than sex, even when she'd propped herself on the pillows in a negligee, legs enticingly ajar. No, what she craved was someone feisty and virile; like Anthony.

Anthony was her son's best friend, and Mrs Dawkins had secretly ogled him since the day she found him sprawled in her lounge room, T-shirt clinging to his torso, joystick gripped fiercely in his slim, strong hands. So smitten had she been by his beauty, it must have shown on her face, because her son, Chris, flushed resentfully at the sight of her and forgot to introduce him. She straightened her features into a suitably maternal expression, asked the gorgeous boy his name herself and then withdrew, though she had returned to offer snacks and drinks more times than was strictly necessary. 
At the time, she had been disturbed and embarrassed by her attraction. Anthony was only sixteen then, and such desires were somewhere between unseemly and downright repulsive. Three years later, however, she began to reconsider. After all, she mused sweatily, he was now a legal adult and at his sexual peak. Besides, didn't most teenage boys have lurid fantasies about older women? And Anthony had always been charming towards her, stopping to chat, flattering her outfits with a flirtatious twinkle. Throbbing beside her snoring husband night after night, she remembered that twinkle and decided it was worth a try.

The tricky part would be getting Anthony alone. Whenever she saw him he was, inevitably, in the company of her surly son, who would be appalled by the idea of his mother having sex at all, let alone with his best friend. Somehow, Chris would have to be lured out of the picture so that Anthony could be lured into her bed.

Mrs Dawkins speculated Thursday was the best day to make her move. Neither Chris nor Anthony had lectures on Thursday afternoons, and they usually came over at two or so to have lunch and play on the Xbox until fourthirty, when Chris left for a late afternoon tutorial and Anthony went home. The thing to do, she thought, was find some way to stop Anthony from leaving or call him back, after which they could have two hours alone in the house together before Mr Dawkins returned from work.

When Thursday arrived, Mrs Dawkins spent the early morning preparing a selection of tempting buns, and the late morning comparing the merits of the outfits at which Anthony had twinkled. At one-thirty she finally decided on her cherry-red pencil skirt and a sleeveless black top in a silky fabric that caressed her body as she moved. Tweaking the top to reveal a hint of cleavage, she slid into the leather armchair in the lounge to await the arrival of the two young men. By the time she heard the rattle of the front door and the thud of two backpacks being flung against the wall in the entry hall, her entire body was pulsing with excitement. As usual, Chris slouched past her to the television with an inarticulate grunt and Anthony paused by the armchair with an engaging grin.

'Hello Mrs D, looking lovely again today! How are you?'

The twinkle she had hoped for lit his sultry dark eyes, making goosebumps mushroom under her top.

'I'm . . . fine, thank you!' she replied breathlessly, and rushed out into the entry hall.

As she clung to the hatstand, trying to compose herself, her eye caught the 
corner of Anthony's university diary, its corner peeking out of the battered green backpack he carried each day, and a plan surfaced in her simmering mind. Very quietly, she undid the drawstring of the backpack, drew out the diary, and turned to the personal information page in the front where Anthony had written his contact details. Congratulating herself, she secreted the diary in the coat cupboard and tiptoed back to the kitchen through the sound of exploding spaceships. At twenty-five past four, she slipped a batch of uncooked buns into the oven and then picked up her handbag and approached the screen full of aliens.

'Hi boys,' she said, in what she hoped was a normal, motherly voice. 'I'm just off to the shops for a couple of hours. Will you be right to see yourselves out?'

'No, Mum, we've forgotten how to operate the door,' replied Chris sarcastically. 'We'll be fine thanks, Mrs D,' added Anthony with a melting smile, 'see you soon!'

Devoutly hoping so, Mrs Dawkins hurried outside to the car, drove around the corner and waited for about eight minutes, by which time she judged that the boys would have left the house, and the buns would not yet be burnt. Returning to the house, she opened the front door again and was relieved to find the lounge room empty and the air ripe with the aroma of freshly baked buns. She retrieved the university diary from the coat cupboard and grabbed the telephone. All she would need to do was call Anthony's mobile, and tell him she'd come home to turn off the oven and found his diary. When he arrived, Chris would be safely on the bus and Anthony would find a table full of fresh buns and an older woman fantasy ready for the taking.

The phone at the other end started to ring and Mrs Dawkins' pulse began to climb. Anthony lived only a few blocks away, and he would be back here within five minutes. She imagined his breezy, muscular walk, and her pulse climbed higher still. The phone rang and rang and finally switched over to message bank.

'Hi! You've called Anthony, and got his message bank instead. Sorry about that. If you leave a message, he might call you later. Bye!'

Mrs Dawkins hung up and sat frowning. His mobile had definitely been ringing, so it couldn't be flat or switched off. Was he on a busy road where he couldn't hear it? She waited a few minutes and tried again, and this time she noticed something strange. Sitting on the kitchen stool with the phone in her hand, she could hear what sounded like popular music coming from directly above her. Had Chris left his stereo on upstairs?

Anthony's phone switched to message bank once more, and she hung up 
again. The music stopped, but now she was listening for it, she could hear other sounds coming faintly through the ceiling, as if someone was opening a drawer. Had a burglar entered the house while she was out?

Mrs Dawkins grabbed an umbrella and tiptoed up the stairs, her heart now pounding with fear instead of lust. She heard the drawer closing again, nearer this time, and the sound was coming from behind the closed door of her son's room, where he kept CDs and expensive electrical goods. Mustering her courage, she flung open the door and jumped into the room, brandishing the umbrella like a sword. A second later, she reeled back against the doorframe in shock.

The bedcovers had been stripped to the floor, and on the bare mattress lay Chris and Anthony; their naked limbs tangled around each other like clothes in a tumble drier. For a moment they went rigid, and then Chris shoved Anthony off him and grappled desperately for the discarded sheets and blankets, trying to cover them both and screaming at her to 'Get out, get out.' Mrs Dawkins stumbled over the two backpacks now on the bedroom floor and half-fell down the stairs in her eagerness to comply. For the two minutes it took the two boys to dress, thunder down the stairs and flee the house, she cowered in the kitchen, recovering her wits only when the smell of burning buns began to fill the room.

Relieved to have a banal, domestic task to occupy her, Mrs Dawkins opened the windows to clear the smoke and dropped the charred buns one by one into the bin. Groping through her numb brain for something safe to settle on, it occurred to her that she and her son had something in common after all: their taste in men. After all, she could hardly judge Chris for doing the very thing she'd been plotting herself, could she? Really, she thought to herself, it was quite natural that they should both find Anthony desirable. It was in their genes. And with this, strangely comforting reflection, Mrs Dawkins took the last and least charred of the buns, went to the lounge room, and sank into the worn leather beanbag. 